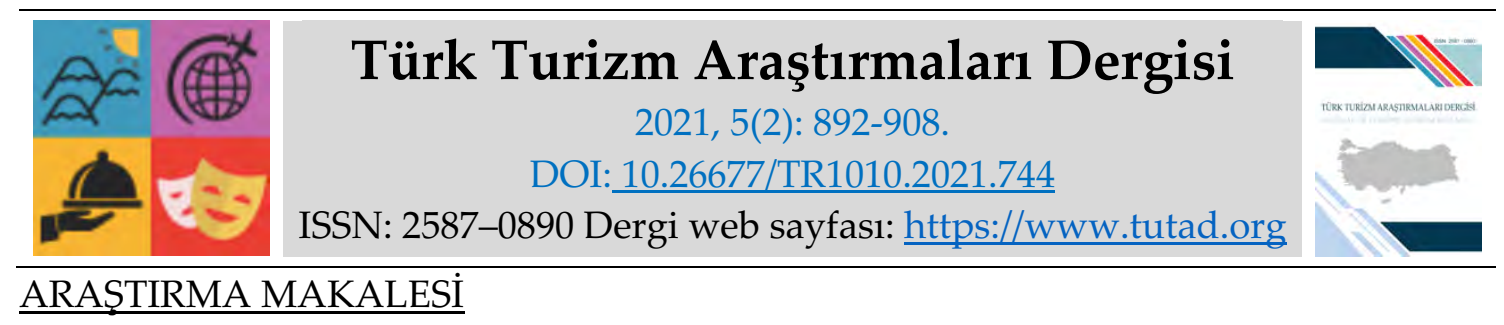

\title{
İstanbul-Beyoğlu Çevresinde Yabancı Turistlerin İlgisini Çeken Özelliklerin Gençler Tarafından Belirlenmesi ve Çözüm Önerileri*
}

İrem KARATAŞ, Yüksek Lisans Öğrencisi, İstanbul Ticaret Üniversitesi, Sosyal Bilimler Enstitüsü, İstanbul, e-posta: iremkaratas05@gmail.com

ORCID: https://orcid.org/0000-0002-5962-0306

Prof. Dr. Nüzhet KAHRAMAN, İstanbul Ticaret Üniversitesi, İşletme Fakültesi, İstanbul, e-posta: nkahraman@ticaret.edu.tr

ORCID: https://orcid.org/0000-0002-3370-1693

\section{Öz}

İstanbul, Türkiye'nin en ünlü ve önemli şehrindendir. Bu kadar önemli olmasının nedenleri arasında coğrafi özelliği, kültürel zenginli ve Asya ile Avrupa arasındaki birleştirici köprü olma gibi özellikleri yer almaktadır. Buna ek olarak birçok topluma ve kültüre ev sahipliği yaptığı için tüm dünyada önemli bir yer edinmiştir. İstanbul dört mevsim turizm çeşitliliği ile turist kabul edebilen bir şehirdir. Gerçekleştirilen bu çalışmada, İstanbul-Beyoğlu çevresinde turistlerin ilgisini çeken özelliklerin 18-25 yaş arasındaki genç bireyler gözünden belirlenmesi hedeflenmiş̧ir. Bu doğrultuda katılımcılara nicel veri toplama yöntemi ile altı soru sorulmuştur. Toplamda 14 katılımının katılımı ile gerçekleştirilmiştir. Çalışmanın amacına bir başka perspektiften bakılacak olursa, İstanbul-Beyoğlu çevresinin yabancı turistler açısından önemli ve merak edilmesinin sebebinin, 18-25 yaş arasındaki gençler tarafından değerlendirilmesi olarak açılanabilmektedir. Bununla birlikte çalışma neticesinde elde edilen cevaplara göre, Beyoğlu ve çevresinin tarihi dokusunun korunması gerekmektedir. Ancak günümüzde korumak yerine tahrip edildiği düşünülmektedir. Ayrıca değişen profili ile de tarihi dokusunun da ve günümüzdeki atmosferinin çok değiştiği belirtilmiştir. Ancak sosyal medya kullanımı ile reklam yapılması konusunda ve edebi eserlere konu olması hakkında olumlu sonuçlar gerçekleşebildiği kanısına varılmıştır.

* İstanbul'a Gençlik Turizmi Kapsamında Gelen Turistlerin Profili ve Seyahat Motiflerinin Araştırılması başlıklı Yüksek Lisans Tezinden türetilmiştir.

Anahtar Kelimeler: Turizm, Özel İlgi Turizmi, Gençlik Turizmi, Sürdürülebilirlik, İstanbulBeyoğlu.

Makale Gönderme Tarihi: 04.12.2020

Makale Kabul Tarihi: 02.06.2021

\section{Önerilen Atıf:}

Karataş, İ. ve Kahraman, N. (2021). İstanbul-Beyoğlu Çevresinde Yabancı Turistlerin İlgisini Çeken Özelliklerin Gençler Tarafından Belirlenmesi ve Çözüm Önerileri, Türk Turizm Araştırmaları Dergisi, 5(2): 892-908.

(c) 2021 Türk Turizm Araştırmaları Dergisi. 


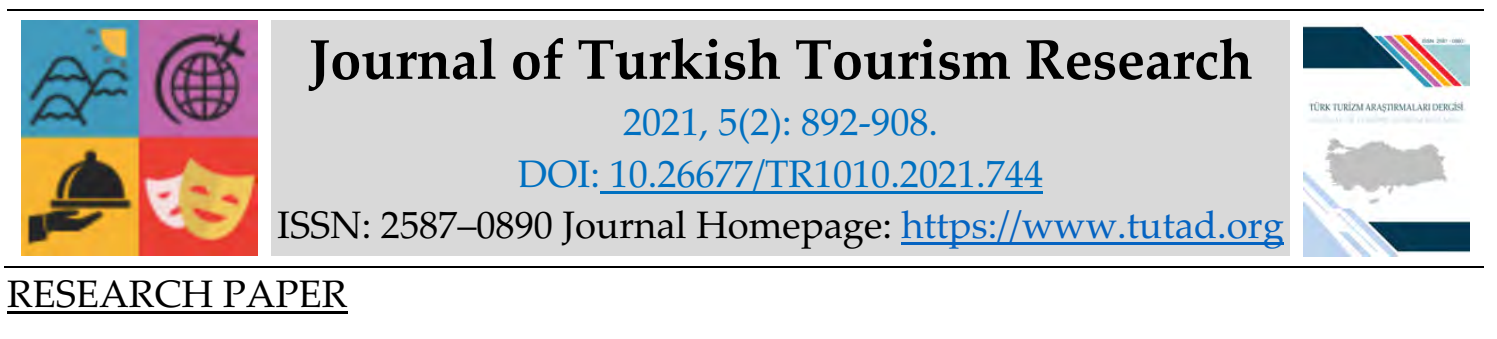

\title{
Determination of Features Attracting Foreign Tourists in Istanbul-Beyoğlu Area by Youth and Solution Proposals
}

İrem KARATAŞ, MSc. Student, İstanbul Commerce University, Social Sciences Institute, İstanbul, e-mail: iremkaratas05@gmail.com

ORCID: https://orcid.org/0000-0002-5962-0306

Prof. Dr. Nüzhet KAHRAMAN, İstanbul Commerce University, Faculty of Management, İstanbul, e-mail: nkahraman@ticaret.edu.tr

ORCID: https://orcid.org/0000-0002-3370-1693

\begin{abstract}
İstanbul, Turkey is from the city's most famous and important. Among the reasons why it is so important are its geographical feature, cultural richness and its characteristics such as being the unifying bridge between Asia and Europe. Also, it has gained an important place in the world as it hosts many societies and cultures. İstanbul is a city that can accept tourists with its four-season tourism diversity. In this study, it is aimed to determine the features that attract the attention of tourists around İstanbul-Beyoğlu from the eyes of young individuals between the ages of 18-25. In this direction, six questions were asked to the participants using the quantitative data collection method. It was carried out with the participation of 14 participants in total. Looking at the purpose of the study from another perspective, the reason why İstanbul-Beyoğlu region is important and curious for foreign tourists can be explained as the evaluation by young people between the ages of 18-25. However, according to the answers obtained as a result of the study, the historical texture of Beyoğlu and its surroundings should be preserved. However, today it is thought to be destroyed instead of protecting it. Also, it has been stated that with its changing profile, its historical texture and atmosphere today have changed a lot. However, it has been concluded that positive results can be achieved with the use of social media in terms of advertising and being the subject of literary works.
\end{abstract}

Keywords: Tourism, Special Interest Tourism, Youth Tourism, Sustainability, İstanbul-Beyoğlu Received: 04.12.2020

Accepted: 02.06.2021

Suggested Citation:

Karataş, İ. and Kahraman, N. (2021). Determination of Features Attracting Foreign Tourists in Istanbul-Beyoğlu Area by Youth and Solution Proposals, Journal of Turkish Tourism Research, 5(2): 892-908.

(c) 2021 Türk Turizm Araştırmaları Dergisi. 


\section{Gíriş}

Seyahat etmek insanlar için dairesel hareketlerle, sadece bir yerden bir yere gitmek değildir. Seyahat etmek, günümüzde insanların temel ihtiyaçları arasında yer almaktadır. İhtiyaçları doğrultusunda gidip, gezip gördükleri yerlerde konaklayarak bir nevi deneyim yaşamaktadırlar (Cavlak ve Cop, 2019). Ancak bu deneyim 15-25 yaş arasındaki gençler için oldukça önem arz etmektedir. Gençlerin kişisel gelişimini en üst düzeyde gerçekleştirebilmeleri adına ve yetişkinliğe geçiş döneminde kendilerini en iyi şekilde düşünebilen, yaşadığı topluma faydalı birer yetişkin olabilmeleri için gezip görerek deneyim sahibi ve toplumlar arası kültürler hakkında bilgi sahibi olabilmeleri oldukça önemlidir (Demir, 2007).

Bir bölgenin tarihi ve kültürel zenginliği turizm açısından oldukça önem taşımaktadır. Turizme bağlı gelişim gösterebilen ulaşım sektörü, yiyecek ve içecek sektörü, konaklama sektörü ve destinasyon yönetimi gibi sektörler turizmle aynı orantılı olarak bölgenin de tarihi ve kültürel zenginliğiyle, gelişim göstererek internet platformlarında da reklamların kullanımıyla ticarileştirilmektedir (Çuhadar ve Kervankıran, 2015; Topuz, 2018). Genç bireyler için ise gezip, görülmeyen yerlere giderek deneyim kazanmak ve en önemlisi en az para ile mümkün olan en uzun seyahati gerçekleştirmek. Ayrıca tarihi yerleri ve müze gibi kültürel yerlerin ziyareti genç turistler için oldukça önem taşımaktadır (Çetintürk ve Küçük, 2019). İstanbul-Beyoğlu çevresi bu tür etkinlikler ve ziyaretler için oldukça önemli yerler olma özelliği taşımaktadır. Sosyal medyanın ve internetin de aktif kullanımı ile artık genç bireyler kimseye ihtiyaç duymadan istedikleri yerleri ziyaret ederek, bölge hakkında bilgi sahibi olabilmektedir (Altuntuğ, 2012).

Bu çalışmada, 18-25 yaş arasındaki genç bireylerin katılımı, çalışma kapsamından katılımcılara yönlendirilen sorular ile İstanbul-Beyoğlu'ndaki atmosfer hakkındaki düşüncelerini belirlemek hedeflenmiştir. Bu sorular ile sırasıyla, İstanbul-Beyoğlu bölgesinin tarihi, ilk seyahat ettiğinizdeki izlenimleriniz ile son gittiğiniz zaman ki izlenimlerinizi karşılaştırmaları, yabancı turistlerin İstanbul-Beyoğlu ve çevresini ziyaret etme durumu hakkındaki düşünceleri, sosyal medyanın İstanbul-Beyoğlu ve çevresinin üzerindeki etkisi ve yerli-yabancı şair ve yazar fark etmeksizin eserlerinde İstanbul-Beyoğlu ve çevresinden bahsetmesini nasıl değerlendirdiklerini saptamaya yönelik gerçekleştiriliştir. Sorularda yer alan olgular aslında turizmin temel ögeleri olan kültürel değerleri içermektedir. Bu doğrultuda katılım sağlayan genç bireylerin düşüncelerine yer verilmiştir.

\section{KAVRAMSAL ÇEVRE}

İstanbul en bilindik özelliği olan coğrafi konumu açısından, Avrupa ile Asya arasındaki birleştirici köprü özelliğidir. Bunula birlikte, şehir olarak, kıtalar arası ve denizler arası ticareti beraberinde getiren bir özelliği vardır. Ayrıca, tarihi zenginliği açısından birçok imparatorluğa başkentlik yapmış bir kent olma özelliği taşımaktadır. Örneğin, Bosphoros denmesinin nedenini Belge (2010) şöyle özetlemiştir: "Yunan Mitolojisinde Zeus'un önce baştan çıkarıp sonra da karısı Hera'nın kıskançlık intikamından korumak için inek kılığına soktuğu İo, Hera'nın üstüne saldığı sineğin tacizinden kaça kaça Boğaz kıyısına gelir ve yüzerek Asya kıyısına çıkar. Bu nedenle buraya Bosphoros denmiştir. (Bous yani İnek + phoros yani geçit): İnek geçidi". Dolayısıyla İstanbul hem konumu açısından hem de tarihi açıdan yaptığı ev sahipliğiyle dünya açısında büyük bir öneme sahiptir. Deniz aşırı geliştirilen ticaretler sonucunda hem yeni yerleşim alanları keşfedilmesine hem de ticari açıdan korunaklı güvenli ulaşım yolları ortaya çıkmıştır. Ayrıca İstanbul, Roma İmparatoru Severus tarafından tahrip edilerek kente en acı şekilde zarar verilmiştir. Yen. İstanbul'un oluşumu yani İ.S. 324'ten sonrası, Severus ile Büyük Konstantin'in katkılarıyla genişletilerek kentte 1600 yıl boyunca sürecek yeni yeni bir tarihin başlamasına ve 
dünya çapında her açıdan oldukça önem arz eden bir İstanbul'un oluşumuna neden olacaktır (Belge, 2010).

İstanbul'un kültür zenginliğini kısaca özetlemek gerekirse, ev sahipliği yaptığı imparatorluklar tarihleri ile Oğuz'un 2011 yılındaki çalışmasında şu şekilde sıralamıştır; M.S.330 - 395 yılları arasında Roma İmparatorluğu, 395 - 1204 Doğu Roma, 1204 - 1261 Latin İmparatorluğu, 1261 1453 Bizans İmparatorluğu, 1453 - 1923 yıllar arası Osmanlı İmparatorluğu ev sahipliği yapmıştır. Buna ek olarak ise Hilafetin 1517 tarihinden sonra Osmanlı devletine geçmesiyle birlikte İslamiyet'in merkezi olarak da kabul edilmiştir. İstanbul'un birçok kültüre ve imparatorluğa ev sahipliği yapmasından dolayı birçok edebi yapıtlarda adından pek çok kez söz ettirmiştir. Geçmişten günümüze kadar gelen birçok yerli ve yabancı edebi eserlerde, kurgusal karakterlerin yaşadıklarına ev sahipliği yapan ve birçok yazarın gezi yazılarında bahsettiği mekân olma özelliği taşımaktadır.

Osmanlı döneminin ilk dönemlerinden Tanzimat dönemi eserlerine kadar olan zaman zarfında, mekânsal betimlemeler daha çok gerçeği yansıtmayan sürekli kendini tekrar eden mecaz anlatımlar içermekteydi. Tanzimat döneminin başında, artık mecaz anlatımlar, yerini daha gerçekçi mekânsal betimlemelere bırakmıştır (Akgül, 2017). Bu dönemlerde kullanılan mekanlar arasında en popüler olanları Beyoğlu ve Galata çevresi olmuştur. Buna ek olarak en popüler olan kentin İstanbul olmasının sebeplerinden biri gerçekleşen değişikliklerin ilk olarak Batı'ya yakınlığından dolayı İstanbul' da yaşanmasından kaynaklanmaktadır. Beyoğlu geçmişten 1940'lı yıllara kadar, çoğunluk olarak gayrimüslimlerin yaşadığı, toplum tarafından farklı görülen tipte insanların genellikle burada yaşadığı ve ayrıca İstanbul'un en alışıla gelmişin dışında, toplumsal normlara uygun olmayan semti olarak yer almaktaydı. Bir nevi Türkiye'nin Avrupa'ya giden basamağı olarak anılmaktaydı (Yaşar, 2012).Bunlara verilecek örneklerden Tanzimat dönemi yazarlarından biri olan Ahmet Mithat Efendi, eserlerinde sürekli İstanbul'daki yanlış Batılaşmaya ve Fransa ile İstanbul'u karşılaştırmaya yer vermiştir (Karabulut, 2010).Yabancı yazardan ise aslen Fransız olan yazar Gustave Flaubert'in 1850 yılında gerçekleştirdiği Doğu Gezisi sırasında İstanbul' da geçirdiği 40 günlük bir zaman dilimini eserinde bahsetmiştir (Oğuz, 2011).

Günümüzde Beyoğlu olarak bilinen, Kağıthane, Şişli, Beşiktaş, İstanbul Boğazı ve Haliç ilçeleri ile çevrili olan eski adıyla Pera, İstanbul Avrupa yakasında yer alan, birçok tarihi zenginli bulunan ilçedir. Orta çağdan günümüze kadar, Yunancada Beyoğlu'nun konumu itibariyle "karşı yaka" anlamında "Pera" olarak da bilinmektedir (Wikipedia). Bununla birlikte en güzel verilebilecek örnek günümüz yazarlarından Ahmet Ümit Beyoğlu'nun mekânsal betimlemelerini, eski hali ve yeni hali şeklinde okuyuculara en belirgin ve canlı şekliyle aktarmaktadır. Ayrıca günümüz romanları eskiye kıyasla İstanbul'un en gerçekçi haliyle yansitılmış kurguları içermektedir (Yaşar, 2012).

Beyoğlu, İstanbul'un kültürel açıdan tam kalbi olarak bilinen ve konum itibariyle de kültür semti olarak kabul görmektedir. 19. yüzyılında Beyoğlu, özellikle Pera adıyla anıldığı dönemlerde, yaşayan kesime ve turistlere, çok kültürlü bir yaşam özelliği ile kültür şehrinin içinde ayrı bir şehir gibi yer alan, ayrı olarak anlatılma imkânı sunmaktaydı. İlçede yer alan elçilikler, konsolosluklar, oteller, modacılar, butik pastaneler, restoranlar, takı ve mücevher dükkanları, tiyatrolar, kiliseler, kabareler, birahaneler gibi mekanlar Avrupa'nın sofistike havasını yansıtmaktaydı. Halen orijinal mimarisi bozulmayan yapıtlar, orijinal yapısına uygun şekilde restorasyon yapılan mimari yapıtlar, Avrupa'dan gelen farklı havasını yansıtmaktadır. 1850'li yıllar ile 1900'lü yıllar arasında Pera, Batılı görünümü ile zevki ve zarafeti yansıttığı, karmaşık bir kozmopolit yapıya sahip olduğu haliyle bilinmektedir. Osmanlı dönemi zamanında dinsel, dilsel, kültürel ve birçok alanda çeşitlilik içermekteydi. Ancak Osmanlı döneminin yıkılış zamanlarında sadece Türk vatandaşı kültürüne önem verildiği ve Beyoğlu olarak anılmaya 
başlandığı zamanlarda, çok kültürlülügün zorunlu olarak azalması ve çeşitliliğin kaybolmasıyla, tek tip yeni düzen meydana gelmeye başlamıştır (Erbey, 2017). Ancak günümüze yaklaşıldıkça Beyoğlu'nun tarihi zenginliğinden kaynaklanan ve Beyoğlu'nda yaşayan yerel halkın baskısıyla birlikte kozmopolitliğe olan duyarlılık, tarihi nostaljik kalıntılarını bozmadan ve küresel kentlik özelliğiyle yeniden markalaşarak varlığını ilerletmektedir. Günümüzde ise Beyoğlu, kozmopolitlik yapısıyla birlikte teknolojinin de gelişmesiyle yeni pazarlama alanlarında olanaklar sağlamaktadır. İnternet aracılığıyla artık Beyoğlu bölgesindeki işletmeler tarihi mimarisiyle birlikte reklam propagandaları yaparak turizm alanında olmakla birlikte birçok ticari alanda olanaklar sağlamaktadır (Aksoy ve Robins, 2011).

Beyoğlu günümüzde ve geçmişte, kültürel zenginliği, kozmopolit yapısı ve gündüz yaşantısı kadar gece yaşantısıyla da oldukça canlı ve dinamik bir kent yaşamına ev sahipliği yapmaktadır. Beyoğlu içerisinde bulundurduğu İstiklal Caddesi'yle bunu gözle görülür bir şekilde, kültürel ve sosyal olarak belli etmektedir. Bu nedenle, Beyoğlu ilçesine yapılan turizm yatırımları ile ilçeye verilen önemli rol her açıdan fazlasıyla desteklenmelidir. Bu yüzden, başta Beyoğlu belediyesi olmak üzere, bir yatırımcı desteğiyle, Beyoğlu'nun turizm potansiyelini arttırmak amacıyla kentsel projelere ve restorasyon alanında geliştirilen projelerle, Beyoğlu'na yeni bir imge kazandırılma çalışmaları, turistik ilerlemelere hizmet eder duruma getirilmiştir. Tasarlanan bu projeler sadece Beyoğlu ilçesi ile sınırlı kalmamaktadır. Turizm kenti olan İstanbul'da, tarihi yerlerde yeni stratejiler ile geliştirici tutum ve davranışlar uygulanmaktadır (Ural, 2017; Yaban ve diğerleri, 2019).

İstanbul'un mimari yapısı geçmişten günümüze kadar, İstanbul' da yer alan her imparatorluktan izler taşımaktadır. Bu imparatorluklar, kendi kültürel değerlerine sahip çıkarak yerleşim alanlarını inşa etmişlerdir. Ancak İstanbul'un planlı ve daha kalıcı yerleşim alanları inşa etmeleri 1800 'lü yılların ortalarına dayanmaktadır. İstanbul'da sürekli yangınlar çımasından dolayı ahşap yapitlarda sürekli bir restorasyon işlemi uygulayarak değişimler meydana gelmiştir. Geçmişten bugüne kadar varlığını koruyabilen yapıtlar şimdilerde turistlik gezilere olanak sağlayarak geçmişin mimarisi hakkında bilgi sahibi olabilmemizi sağlamaktadır. Bahsedilen bu yapıtların yoğunlukta olarak Beyoğlu ve çevresindeki ilçelerde bolca bulunduğu ve yıkık dökük yapılarında azımsanamayacak kadar çok olduğu görülmektedir. Bu yapıtların otel gibi kullanıma açılabilmesi için ilk olarak sosyal çevrenin restore edilebilecek yapıya göre planlanması gerekmektedir. Ayrıca ulaşım alanındaki yetersizliklerde bu ilerlemeyi engelleyebilmektedir (Yildırım, 2018).

Beyoğlu bölgesindeki yapıtların ahşap olmasından kaynaklanan ve büyük yangınlar sonucunda yaşanamayacak duruma gelen yapitların, restorasyon veya yeniden inşa edilen yapitların yabancı mimari yapıtlar niteliği taşıdığı görülmektedir (Dinçer ve Ertuğral, 2000). En önemli yapitlardan Pera Palas bunlara verilebilecek örneklerin başında gelmektedir. Pera Palas otelin mimarı ünlü Fransız asıllı Alexandre Vallaury'dır. Alexandre bu yapıtında döneminin en yeni ve en modern mimarisini ortaya çıkarmıştır. Bu yapıtta ilk kez asansör, çelik iskelet ve tuğla kullanılmıştır. Beyoğlu ve çevresindeki yapıtların tipik örneğini içermektedir. O dönemlerde inşa edilen yapıtlar günümüzde genellikle konaklama alanında restore edilmiş ve otel olarak hizmet vermektedir (Çelebioğlu ve Yergün, 2019).

Tüm bu gelişeler ile birlikte teknoloji de oldukça hızlı bir şekilde gelişip büyümüştür. Ulaşım araçlarının oldukça sık kullanımı, internetinde oldukça yaygın kullanımıyla insanlar için seyahat etmek artık bir ihtiyaç halini almaya başlamıştır. Gerçekleştirilen seyahatlerin nitelikleri insanların refah düzeylerine bağlı kalarak ve sosyal medya platformlarının da yaygın kullanımına göre yeniden şekillenmiştir ve değişen koşullara göre de değişime devam etmektedir (Doğan, Pekiner ve Karaca, 2018). Seyahat edilen bölgelerde, turistlerin özellikle sık sık ziyaret amaçlı tercih ettikleri yerlerin tarihi mekanlar ve kültürel zenginliği olan mekanlar olduğu 
bilinmektedir. Ancak turistlerin ve yerel halkın bu mekanlara saygı göstererek koruması ve değerlere sahip çıkması gerekmektedir. Aksi halde her iki grup içinde istenmeyecek şekilde olumsuz sonuçlara yol açabilecektir. Bununla birlikte, yöneticiler bir bölgeyi ticarileştirerek, turizme açık bir şekilde sunmadan önce yerel halkın kültürel mirasına sahip çıkarak, ulusal ve uluslararası kültürel mirasın tüketimini engelleyebilecektir (Erbaş, 2019). Bu doğrultuda İstanbul-Beyoğlu çevresi oldukça önem taşımaktadır.

Sosyal medya kullanımının artmasıyla insanlar, özellikle genç bireyler, bölgeler hakkında detaylı bilgi sahibi olabilmektedir. Buna ek olarak kimi zaman genç turisteler seyahat edecekleri bölgede yaşayan bir kesim yerel halkın bile gidip görmediği yerleri öğrenerek ziyaret ettiği bilinmektedir (Başbayram ve Turan, 2018). Bu doğrultuda yöneticilerin kültürel mirası koruyarak, geleneklere ve göreneklere, inançlara ve efsanelere, edebiyata, sanata, dans ve tiyatro gibi sahne sanatlarına saygı duyarak sosyo-kültürel yapıyı koruması gerekmektedir.

Alanyazında verilmiş olan bilgileri özetlemek gerekirse, İstanbul geçmişten günümüze kadar birçok imparatorluğa, devlete ev sahipliği yapmıştır. Bunun en önemli sebepleri arasında İstanbul'un konumu ve buna bağlı kalarak ticaret yolları açısından oldukça önem taşıması yer almaktadır. Bunların beraberinde gelen geçmiş dönemlerde önde gelen yazar ve şairlerin eserlerinde İstanbul-Beyoğlu çevresinden oldukça söz etmeleriyle birlikte insanlardaki merakı tetikleyen ve turistik bir destinasyon olmasını pekiştiren bir özellik olmasına yol açmıştır. Tüm bu özellikler göz önünde bulundurulduğunda ve günümüze gelindikçe sosyal medyanın da önemli etkisi göz önünde bulundurulduğunda şu an ki turistler için destinasyon tercihlerini olumlu yönde etkilediği görülmektedir.

\section{ARAŞTIRMANIN YÖNTEMI}

15-25 yaş arasındaki genç bireylerin turistik hareketlilikleri gençlik turizmi olarak adlandırılmaktadır. Bu hareketlilik, ülkelere diğer turizm çeşitlerinden daha fazla getiri getirdiği için ülkeleri, yatırım yaparak ve gençlere yönelik turizm pazarlama stratejileri hazırlayarak, yeni çalışmalar ortaya koymaktadırlar. Bununla birlikte, ülkelerin, genç bireylerin geliştirici ve aydınlatıcı gücüne ihtiyaçları her geçen gün artmaktadır. Ülke politikaları artık genç kuşağa yönelik artış göstermeye başlamıştır. Dolayısıyla 15-25 yaş arasındaki bireyler oldukça önem arz etmektedir. Gerçekleştirilmiş olan bu çalışmada 18-25 yaş arasındaki katılımcılar tercih edilmiştir. Bunun sebebi bu yaş aralığındaki bireyler, ailelerinden daha bağımsız hareket edebildiklerinden dolayı, her yeri özürce ziyaret ederek, gezip görebilmekteler (Kazandzhieva ve Popova, 2017; Karataş, Altun ve Cizrelioğulları, 2020).

Çalışmanın evreni, birçok imparatorluğa ev sahipliği yapmış ve halen geçmişten izler barındıran, yılın dört mevsimi, turistlerin çoğunlukta ziyaret ettiği ve dünya çapında başta coğrafi konumundan kaynaklı olmakla birlikte, bilinen kent destinasyonu İstanbul-Beyoğlu ve çevresi tercih edilmiştir. Gerçekleştirilmiş olan çalışmanın asıl amacı, çalışmada temel alınan görüş ve önerilerin, 18-25 yaş arasındaki genç bireylere ait olması hedeflenmektedir. Bir başka pencereden bakılacak olursa, bu çalışma, 18-25 yaş arasındaki genç bireylerin, alternatif turizm çeşitlerinden gençlik turizmi adı altında, yılın dört mevsimi sürekli seyahat etmelerinden dolayı, doğdukları dönem şartları ve büyüdükleri dönemin şartlarından, sürekli kendilerini okuyarak geliştirebildikleri ve sosyal medyayı en aktif şekilde kullandıkları için İstanbul-Beyoğlu çevresi hakkındaki görüş ve önerilerini temel almak amaçlanmıştır. Bu doğrultuda katılımcılara bu düşüncelerinin ifade edebilmeleri adına konuyla ilgili hiçbir siyasi içerikli ve ifade barındırmayan altı soru sorulmuştur. Dolayısıyla katılımcıların görüş ve önerilerini hiçbir baskı altında kalmadan özürce ifade edebilmeleri adına çalışmaya katılımın tamamen gönüllülük esaslı olduğu bildirilmiştir. 
Çalışma kapsamında katılımcıların 18-25 yaş arasında, gençlik turizmine hitap eden bireylerin katılımı ile gerçekleştirilmiştir. Bununla birlikte katılımcılar arasında herhangi bir ayrıştırma şeklinde bir gruplandırma yapılmamıştır. Gerçekleştirilen bu çalışmada, katılımcıların görüş ve düşünceleri hakkında doğrudan bilgi sahibi olabilmek adına nitel veri toplama yöntemi kullanılmıştır. Katılımcılara yönlendirilen sorular daha önce gerçekleştirilmiş olan çalışmalar dikkate alınarak hazırlanmıştır (Acır, 2010; Yaşar, 2012; Kahraman, 2014; Atan ve Arslantürk, 2015; Başbayram ve Turan, 2018; Aratimur ve Akgündüz, 2018; Zengin, Kıngır ve Tezcan, 2018; Soylu, Özdipçiner ve Ceylan, 2018). Covid-19 virüs sebebiyle katılımcılara yüz yüze soruları cevaplatmak yerine, katılımclara Google form ile internet ortamında sorular yönlendirilerek cevaplatılmıştır. Katılımcılara yönlendirilen demografik sorular yaş, eğitim durumu, çalışma durumu ve sürekli ikamet adresleri dışında aşağıda listelenmiş olan 6 soru ek olarak sorulmuştur.

1. İstanbul-Beyoğlu'nu ziyaret etme sıklığınız?

2. İstanbul-Beyoğlu bölgesinin tarihi dokusunu nasıl değerlendiriyorsunuz?

3. İstanbul-Beyoğlu bölgesinin tarihi dokusunu ilk seyahat ettiğinizdeki izlenimleriniz ile son gittiğiniz zaman ki izlenimlerinizi nasıl karşılaştırıyorsunuz?

4. Yabancı turistlerin İstanbul-Beyoğlu ve çevresini ziyaret etme durumunu nasıl değerlendiriyorsunuz?

5. Sosyal medyanın İstanbul-Beyoğlu ve çevresinin üzerindeki etkisini nasıl değerlendiriyorsunuz?

6. Yerli-yabancı şair ve yazar fark etmeksizin eserlerinde İstanbul-Beyoğlu ve çevresinden bahsetmesini nasıl değerlendiriyorsunuz?

Katılımcılara yönlendirilen sorular ile katılımcıların düşünce ve görüşlerinin belirlemeye yönelik cevaplar elde etmek hedeflenmiştir. Bir başka bakış açısı ile araştırma sonucunda, katılımcıların deneyimlerinin ve tecrübelerinin birikimleri sonucunda daha pratiğe geçirilebilecek öneriler ve sonuçlar ortaya çıkarmak hedeflenmiştir.

\section{BULGULAR}

Katılımcların demografik bilgileri Tablo 1'de verilmiştir. Buna göre, katılımcıların demografik bilgileri incelendiğinde, yaş oranlarına göre en düşük yaş 22 iken, en yüksek yaşa sahip katılımcılar ise 25 yaşındadır. Katılımcıların eğitim durumlarına göre sırasıyla, \%50'si lisans, $\% 28,6$ 's1 yüksek lisans ve son olarak \%21,4 doktora olarak belirtmiştir. Katılımcıların sürekli ikamet ettikleri şehirlere bakıldığın ise \%85,7'lik oran ile İstanbul olduğu görülmektedir.

Tablo 2 incelendiğinde ise, katılımcıların İstanbul-Beyoğlu'nu ziyaret etme sıklığı hakkındaki bilgiler verilmiştir. Tablo incelendiğinde, araştırmaya katılan katılımcıların ziyaret sıklı̆̆ına göre, en az yılda bir kez, en fazla her gün Beyoğlu'na ve çevresine gittikleri görülmektedir. 
Tablo 1. Demografik Bulgular

\begin{tabular}{|c|c|c|c|}
\hline Değişkenler & & $\mathrm{N}$ & $\%$ \\
\hline \multirow[t]{4}{*}{ Yaş } & 22 & 2 & \\
\hline & 23 & 5 & \\
\hline & 24 & 5 & \\
\hline & 25 & 5 & \\
\hline \multirow[t]{3}{*}{ Eğitim } & Lisans & 10 & \\
\hline & Yüksek Lisans & 4 & \\
\hline & Doktora & 3 & \\
\hline \multirow[t]{4}{*}{ Çalışma Durumu } & Öğrenci & 2 & \\
\hline & Çalışıyor & 8 & \\
\hline & Çalışmiyor & 6 & \\
\hline & Freelance & 1 & \\
\hline \multirow[t]{5}{*}{ Sürekli İkamet Adresiniz } & İstanbul & 14 & \\
\hline & Lüleburgaz & 1 & \\
\hline & Ordu & 1 & \\
\hline & Giresun & 1 & \\
\hline & nc1 17 & & \\
\hline
\end{tabular}

Tablo 2. Katılımcıların İstanbul-Beyoğlu'nu Ziyaret Etme Sıklığ1

\begin{tabular}{ll}
\hline \hline 1. Katılımc1 & Ayda 1 \\
2. Katılımc1 & Yılda 1 \\
3. Katılımcı & Yılda 1 kez \\
4. Katılımc1 & Yılda 2-3 kez. Ancak yıl içerisinde gelen misafirleri gezdirmek için 4-5 kez olabiliyor. \\
5. Katılımc1 & Haftada 1 \\
6. Katılımc1 & 2 ayda bir \\
7. Katılımc1 & Ayda 1 \\
8. Katılımc1 & Ayda birden fazla \\
9. Katılımc1 & Değişkenlik gösteriyor ama ortalama ayda3kez falan \\
10. Katılımc1 & Ayda bir \\
11. Katılımc1 & Haftada 3 gün \\
12. Katılımc1 & Her gün \\
13. Katılımc1 & Müsaitlik durumuma göre ayda 1 kez \\
14. Katılımc1 & Hemen hemen her hafta \\
15. Katılımc1 & Sene de en az 2 kez giderim \\
16. Katılımc1 & Her gün \\
17. Katılımc1 & Her yıl ziyaret etmekteyim. \\
\hline
\end{tabular}

Katılımclara yönlendirilen İstanbul-Beyoğlu bölgesinin tarihi dokusunu nasıl değerlendirdikleri hakkındaki düşünceleri Tablo 3'de verilmiştir. Bu doğrultuda yanıtlar incelendiğinde ortaya genel olarak tarihi dokusunun oldukça zengin oluğunu, popüler bir bölge olduğunu ancak 
günümüzde tarihi dokusunun tahrip edildiğini, gerekli saygının gösterilmeyip karışık ve düzensiz bir yapılaşmanın var olduğunu ve iyileştirici önlemler alınması gerektiğini belirtmektedirler.

Tablo 3. Katılımcıların İstanbul-Beyoğlu Bölgesinin Tarihi Dokusunu Değerlendirmesi
1. Katılımc1
Kozmopolit bir şehir olması sebebiyle tarihi dokusu birçok milletten iz taşıyor.
2. Katılımc1
Beyoğlu'nun tarihi dokusu anlatılmakla bitmez. Galata kulesi, taksim meydanını gezdiğinizde bu güzelliklerin farkına varıyorsunuz. Bu tarihi dokuyu gezmeden anlayamazsiniz.

3. Katılımc1

Her geçen gün tahrip ediliyor.

Ben doğma büyüme İstanbul'dayım. Beyoğlu ve çevresinin tarihi dokusu oldukça fazla hissedilmektedir. Binaların mimari, turistlerin yoğunlukta

4. Katılımc1 olarak o bölgelerde bulunması, geçmişteki gibi günümüzde de batıya ilk basamak olma özelliği ile diğer bölgelere nazaran aykırı bir havası olduğunu düşünmekteyim.

5. Katılımc1 1870 yangınından sonra yapılan binalar oldukça etkileyici. Tarihi yarımada gibi Osmanlı izleri değil, daha modern izler taşıyor.

6. Katılımc1 Eski yapılar ile yeni yapılar birbirine girmiş durumda, tarihi doku hissedilmiyor.

Bölgenin tarihi yapısının bozulmaması ve yapılanmaya açık olmamasını

7. Katılımc1 umuyorum. Bölgenin tarihi dokusu hem yerli hem de yabancı turistler tarafından görülmesi ve değer görmesi turistik anlamda oldukça ülkemize olumlu katkı sağlamaktadır.

8. Katılımc1 Tarihi yapıların bölgede yapılan bazı restorasyon ve peyzaj çalışmalarına rağmen varlıkları sürdükleri söylenebilir.

9. Katılımc1 Tarihi olarak harika bir bölge.

Farklı kültürlerin oluşturduğu kolektif fakat talan edilmiş bir miras

10. Katılımc1 olarak görüyorum. Türk modernleşmesinin mekânsal hafızası olarak değerlendiriyorum.

11. Katılımcı Geçici ve enerjik.

12. Katılımcı Kaybolmaya başlamış.

13. Katılımc1 Mevcut tarihi dokularla oynamadığı sürece gayet iyi buluyorum. Daha da iyi olabilir ama

14. Katılımc1 Şu an da hem eski dokusu var hem de yenilenmiş bir doku var. Her iki atmosferi hissedebiliyorsun.

Evet meşhur Pera kitaplara aşklara yeniliklere kucak açmış birçok dinin 15. Katılımcı ve dilin birleştiği İstanbul'un uyumayan en popüler ve camlı bölgelerinden biri Beyoğlu.

16. Katılımc1 Çok güzel tarihi yerleri var daha da güzel değerlendirilebilir.

Her köşesi, her yapısıyla bizlere geçmişimizi yansıtması ve hatta tarihi 17. Katılımcı yapılarıyla o dönemleri yaşanılır kılması İstanbul-Beyoğlu bölgesini daha özel ve anlamlı hale getirmektedir.

Katılımcların, Beyoğlu ve çevresine ilk seyahat ettiğindeki izlenimleri ile son gittiğindeki izlenimlerindeki karşılaştırma Tablo 4' de verilmiştir. Buna göre katılımcıların yorumlarından ilk 
gittiklerinde her şeyin daha eskisi gibi olduğunu, gelen ziyaretçilerin günümüzden daha farklı olduğunu ve mimarisinin de çok farklı olduğunun sonucuna varılmıştır. Ayrıca bu durumun olumlu olmayıp, olumsuz yönde olduğunu belirtmektedirler.

Tablo 4. Katılımcıların İlk Seyahat ile Son Seyahatini Karşılaştırması

1. Katılımc1 Büyük bir değişim görülmektedir. Gün geçtikçe kötüye gittiğini düşünüyorum. İlk gittiğim zaman akşamdı. Tarihi dokuları akşam görme fırsatına sahip

2. Kat1limc1 olmuştum. Son gidişim de tarihi güzellikleri keşfedebilmek için gündüz saatlerini tercih etmiştim. Beyoğlu'nun gecesi ayrı güzel gündüzü ayrı.

3. Katılımcı Tarihsel dokusuna önem verilmeksizin yok ediliyor

Babaannemler Kasımpaşa'da oturdukları için küçükken sık sık giderdik. Neredeyse haftada 1-2 kez. O zamandan bu zamana neredeyse 10 yıl var. Geçmişten bugüne değerlendirdiğimde ise geçmişte tarihi dokunun ve atmosferin daha fazla hissedildiğini söylemem gerekmektedir. Kentsel 4. Katılımcı dönüşümler adı altında eski dokusunun kaybolmasına neden olduğunu düşünmekteyim. Tarihi yapıtları en baştan yıkılması yerine orijinalliği bozulmadan düzgün bir şekilde restore edilmesi gerektiğini düşünmekteyim. Ayrıca bölgede yer alan dükkanların daha çok fabrikasyon ürünler yerine daha çok el işi ürünler içermesi gerektiğini düşünmekteyim.

İlk gittiğimde binalara dikkat etmemiştim, sadece kalabalığı rahatsız edici

5. Katılımcı bulmuştum. Artık her bir yapısını ayrı ayrı biliyorum ve hayranlık duyuyorum. Elbette yeni yapılan cami, akım vs. değil. Bunlar tarihi dokuya saygısızlık.

6. Katılımcı Bölge çok betonlaştı, eski havası yok gibi. Turizm açısından sahip olunan değerler daha öne çıkarılmalı, daha iyi sunulmalı.

7. Katılımcı Zamanla yapılaşma ve tarihi dokunun yok edilmeye çalışılması oldukça üzücü.

8. Katılımcı Bölgede yapılan meydan düzenlemeleri ve restorasyon çalışmaları tarihi yapıların mimari estetiğine zarar verdiği ya da gölgelediği söylenebilir.

9. Katılımcı İlki de 2 yıl önceydi çok karşılaştırma olur mu bilmiyorum ama tarihi halini korumak yerine, yenilemeye çalıştıkları, uygunsuz düzenlemeler yaptıkları kesin

10. Katılımc1 İlk gittiğimde küçük bir çocuktum ve barok cepheler, anıtsal yapılar çok etkileyici gelmişti. Şimdi ise dikkat çeken unsur kalabalık, beton ve kötü görüntü.

11. Katılımc1

Merkez ve Etkileyici- Sadece merkez

12. Katilımc1

Giderek yok oluyor var olan tarihsel doku

13. Katılımcı

Arasında çok fark göremiyorum, ilk gittiğimde de aşırı kalabalıktı son gittiğimde de aynı kalabalıktı.

İlk gittiğim zaman eski insanlar, eski restorana ve dükkanlar vardı. Sokaklarında

14. Katilımc1 daha fazla müzik vardı. Mağazaları da bir o kadar kaliteliydi. Yani eskisinde tarih vardı. Çiçek pasajındaki insanlar, Rum müzikleri, vs. Şu an ise yerli halk ve turist profili olumsuz yönde etkilenmiş. Düzensizlik var.

15. Katılımcı Beşerî dokusunda yozlaşma bulunsa da tarihi doku olarak her gittiğinizde yeni yerler keşfediyorum.

16. Katilımc1

Önceden daha eski evler kafeler ve mekanlar vardı. Ancak şu an daha modern bir hal aldı. Ama hala daha tarih kokuyor.

17. Katılımc1 Eski ve yeni haliyle İstanbul/Beyoğlu eski tarihi dokusuyla kültürel alanda, ticari ve turizm alanında ilk tercih edilen bölgedir.

Katılımcıların, yabancı turistlerin İstanbul-Beyoğlu ve çevresini ziyaret etme durumu hakkındaki düşünceleri Tablo 5'de verilmiştir. Elde edilen bilgiler sonucunda katılımcıların, bu durumu olumlu olarak değerlendirdikleri ve bu bölgenin turistler için birebir ziyaret etme motivasyonu 
içerdiğini düşünmektedirler. Ancak kıyaslama yapan katılımcıların eskiye nazaran günümüzde insanların daha az ziyarette bulduklarını belirtmektedirler.

Tablo 5. Katılımcıların Yabancı Turistlerin Ziyaret Etme Durumunu Değerlendirmeleri

1. Katılımc1

2. Katılımc1

3. Katılımc1

4. Katılımc1

5. Katilımc1

6. Katılımc1

7. Katılımc1

8. Katılımc1

9. Katılımc1

10. Katılımc1

11. Katılımc1

12. Katılımc1

13. Katılımc1

14. Katılımc1

15. Katılımc1

16. Katılımc1

17. Katılımc1
Daha çok Arapların tercih etmesi bölgede ki yönelimi değiştirdiğini düşünüyorum.

Turistlerin böyle güzellikleri ülkemize gelerek ziyaret etmelerini doğru buluyorum.

Turist yoğunluğu sadece belirli bölgelerinde mevcut ve geçiş güzergahı olarak kullaniliyor.

Yabancı turistler için oldukça güzel olduğunu düşünmekteyim. Çünkü gittiğim ülkeler ile kıyaslandığımda bölgenin mimarisi Avrupa ile hemen hemen aynı özellikleri taşımakta. Böylelikle kendi kültürlerinde izlenimler duymakta olduklarını düşünüyorum. Beyoğlu çevresinin bu açıdan önemli bir yer olduğunu düşünmekteyim.

Her zaman eğlence turizmi için önemli bir yer olmuştur. Son zamanlarda alışveriş turizminin fazlalaştığını görüyoruz. Özellikle İstiklal de yaşanan bombalı saldırılardan sonra turistlerin daha az uğradığı bir yer olmuş, yeni yeni tekrar turist kazanmaya başlamıştır. Fakat son dönem turistler genellikle Arap ve Beyoğlu kültürüne uygun davranmıyorlar. AVM ile Beyoğlu arasında bir fark olduğunu anladıklarını düşünmüyorum.

Ziyaret ediyorlar ama daha iyi pazarlansa, tarihi yapıların ön plana çıkacağı tanıtımlar yapılsa daha çok turist ziyaret eder.

Kesinlikle ülkemize özellikle İstanbul'a gelen turistleri çekme özelliğinden dolayı olumlu katkılar sağladığı görüşündeyim.

İstanbul ile özdeşleşmiş olan başta Taksim meydanı ile İstiklal caddesinin bir sembol olarak yerli ve yabancı turistler açısından ziyaret edilmesi gereken bir turistik destinasyon olduğu söylenebilir.

İstanbul'un en ünlü bölgelerinden biri sık sık geliyorlar, eğlence mekânlarında ilgilerini çekiyor.

İstanbul'un sur içinden sonra gezmeye değer yeri burası olduğu için normal bir durum.

Dokuyu ve kültürü tahrip edici.

Eskisi kadar düzgün değil.

Tarihi değerlerimize bizden çok önem verdikleri kesin.

Çok fazla. Fakat eskiye göre daha fazlaydı ve Avrupalı turistler daha fazlaydı. Ancak bu durum o bölgedeki ekonomiyi birebir etkilemektedir.

O kadar farlı bir havası var ki kim olursa olsun dünyanın neresinden gelirseniz gelin bence Beyoğlu'nda her kültürün geçmişine ait yaşayan izleri var. Bu nedenle yerli ve yabancı turistlerin tercih nedeni. Doğu ve Batının yemek kültürü, eğlence kültürü, dini, dili, hepsinden var keşfetmesini bilene

Beyoğlu'na bağlı olan özellikle taksimi de çok sık ziyaret ediyor ve çokça turist ağırladığına şahitlik ediyorum. Bence en çok turist ağırlayan yerlerin basında Beyoğlu geliyor.

Bölgenin kültürel, ekonomik ve sivil hayatın gelişmesinde turizm ve turist ziyaretlerinin olumlu etkisi olduğunu düşünüyorum. 
Tablo 6. Katılımcıların Sosyal Medyanın Etkisini Değerlendirmesi

Sosyal medya her şey üzerinde olduğu gibi İstanbul tanıtımında da

1. Katılımc1

etkili bir rol oynamaktadır. Tanıtımın nasıl yapıldığına dikkat

edilmelidir.

Sosyal medya insanlarda merak uyandırıyor. Arkadaş çevresinin

2. Katılımc1

paylaşımlarında Beyoğlu'nun güzelliklerini gören kişiler meraklarını gidermek için ziyarete gidiyorlar.

3. Katılımcı Çok fazla aktif bir yayın bulunmuyor.

Sosyal medyada özellikle İnstagram'da gidip gezilecek yer adlı profiller

4. Katilımc1

ile bu bölgelerde var olan gezilecek yerlerin tanıtımı yapılmaktadır.

Bana kalırsa sosyal medyada bu tür farkındalıklar ile tarihi ve kültürel mirasa sahip çıkılabilmesi adına farkındalık yaratılabilir.

5. Katılımc1

Gezi zamanlarından önce eğlence için çok yayınlanıyordu, Gezi

olaylarında da görseller arttı. Şu an bir etkisi olduğunu düşünmüyorum.

Sosyal medya günümüzde doğru kullanıldığında her konuda olduğu

6. Katılımc1

gibi bu konuda da etkisi olacaktır. Ama sosyal medyada nasıl bir çalışma var bilgim yok Beyoğlu bölgesi için.

7. Katılımc1

8. Katılımc1

Olumlu etkilediğini düşünüyorum. İnsanlar üzerinde daha fazla merak ve keşfetme duygusu oluşturması bölge için olumlu etki yaratmaktadır. Özellikle bölgede bulunan tarihi ve kültürel yapılar başta olmak üzere sokak sanatçılarının eserlerini, gösterilerinin sosyal medyada tanıması hem bölgenin tanıtımına hem de ziyaret edilmesi üzerinde bir niyet uyandırdığı söylenebilir.

9. Katılımc1

Fazla paylaşım yapılan, tartışılan, olaylarla karşılaşılan bir alan, popülerliğini artırıyor ve tabi bölgeye yapılan müdahaleyi de.

Sosyal medyanın etkisi belki gençler üzerinde farkındalık uyandırıyor olabilir bazı kültürel miras eserlerine zarar verileceği veya verildiğ $i$

10. Katılımc1 zaman sosyal medyadan görüyor veya örgütleniyoruz. Bunun dışında bilgilendirici sosyal medya hesapları sayesinde Pera bölgesi tarihini öğrenenler oluyor olabilir.

11. Katılımc1 Tarihi yapılara yönelik tanıtım yapılmalı, turlar düzenlenmeli, çevre düzenlemesi ve temizliğe önem verilmeli.

12. Katılımcı Geliştirilebilir.

Sosyal medyanın her mecraya olduğu gibi buraya etkisi yoğun bir

13. Katılımcı şekilde hissedilmektedir. Yalnız kötü olanı iyi yönleriyle değil genelde kötü yönleriyle etki altına alması üzücü

14. Katılımc1

15. Katılımc1 Olumlu yönde etkilerinin olduğunu düşünmekteyim. Turizm açısından reklam oldukça önemli.

Tabi ki ekolojinin aktif olarak kullanıldığı günümüzde etkisinin büyük olduğunu düşünüyorum

Öncelikle artık insanlar daha tarihi ve antik tarz kafe ve mekanları daha

16. Katılımcı çok beğenmeye başladı ve sosyal medya da sıkça fotoğraf paylaşıldığını görüyorum.

Sosyal medya birçok platformun bulunduğu ve çok büyük bir kitleye

17. Katılımcı hizmet verdiği için genel ve bireysel paylaşımların insanlar üzerinde olumlu etkisi olduğu nu düşünüyorum. 
Tablo 7. Katılımcıların Şair ve Yazarların Eserlerinde Bahsetmesini Değerlendirmesi

1. Katılımcı Olumlu değerlendiriyorum. Herkes kendinden bir şeyler bulabilir.

Bu güzellikleri şairler, yazarlar eserlerinde bahsederek insanlarda merak

2. Katılımc1 uyandırmayı başarıyorlar. Şairlerin, yazarların eserlerin de Beyoğlu'ndan bahsetmelerini doğru buluyorum.

3. Katılımc1

Dünya mirası olmasından dolayı olduğunu düşünüyorum.

İstanbul-Beyoğlu'nun sadece tatil amaçlı turizm yerine, birçok alternatif

4. Katılımc1 turizm çeşitlerine hitap ettiği için oldukça zengin bir kültüre mirasa sahip olduğu, kitaplara konu olduğu için ve ölümsüzleşeceği için oldukça olumlu bir açıdan değerlendiriyorum.

Çok normal. Sanatın ve sanatçının doğduğu bir yer, etkilenilmemesi 5. Katılımcı imkânsız. 1300'lü yıllardan beri de elçiliklerin, ticaretin burada yer alması hep hatıralarda yer etmesine, gezginlerin notlarına yansımıştır.

6. Katılımc1

7. Katılımc1

8. Katılımc1

Bilgim olmadığı için yorum yapamayacağım.

İnsanlarda merak uyandırması ve gizemi bölgeye çekicilik katmaktadır.

Başta Türkiye olmak üzere bölgenin hem edebi alanda hem de turistik açıdan dünyadaki diğer destinasyonlara kıyasla tanımasına katkı sağladığ1 ve edebiyat turistleri açısından Beyoğlu bölgesinin popüler bir gezi rotası olarak algılanmasına katkı sunduğu söylenebilir.

Eski bir yerleşim alanı, güzel ve dikkat çekici, bir sürü esere konu olacak

9. Katılımc1 kadar güzel olmasıyla ilgili olduğunu, farklı bir ruhu olduğunu düşünüyorum.

10. Katılımc1 İnsan etkilendiği yerleri sanatsal faaliyetlerine de yansitır. İstanbul dahilinde Beyoğlu dışında pek de bahsedecek aynı değerde bir yer yok. Bölgenin doğal çekicilik anlamında bozulmadan özgün kalması

11. Katılımc1 gerektiğini düşünüyorum ve özellikle yabancı turistler tarafından çok ziyaret edilmesi ve beğenilmesi ülkemize olan ve özellikle İstanbul'a turist akışını arttırmaktadır.

12. Katılımc1

Beyoğlu İstanbul'un kalbi ve birçok hayatın kesiştiği bir nokta. Kültürel eserlerde olması çok önemli.

13. Katılımc1

Bu gibi yerlere isim yapmış veya yapmamış şair ve yazarların değinmesi son derece önem teşkil etmektedir. Tarihi dokularımız unutulmamalı.

Eski şairlere ve yazarlara göre eski dokusunu yansıtmakta. Günümüz şair

14. Katılımc1 ve yazarları günümüzü anlatıyor. Beyoğlu ve çevresini her şair ve yazar gezip gördüklerini yansitıyor. Bu durum bizlere eserlerin yazıldığı dönemler hakkında bilgi verdiğini düşünmekteyim.

Çok olumlu buluyorum mesela Değerli Yazar sanatçı çok yönlü güzel insan Zülfü Livaneli'nin Serenat romanının 34 ülkede yayınlanması

15. Katılımc1 okumayı seven insanların buraları merak edip ülkemizi ziyaret etmesi çok güzel bir duygu.

16. Katılımc1 Çok normal. Çünkü tarihle iç içe.

17. Katılımcı Birçok sanata, esere konu olan Beyoğlu'nun insanlar üzerinde merak uyandırdığını düşünüyorum.

Tablo 6 incelendiğinde, katılımcıların sosyal medyanın İstanbul-Beyoğlu ve çevresinin üzerindeki etkisini nasıl değerlendirdikleri hakkındaki düşünceleri yer almaktadır. Tablo incelendiğinde, katılımcıların düşünceleri doğru bir şekilde kullanıldığında ve düzgün bir 
şekilde reklamlar yapıldığında sosyal medya kullanıcısı açısından daha bilgilendirici olabileceği düşüncesi ortaya çıkmaktadır.

Son olarak Tablo 7'de katılımcıların şair ve yazarların eserlerinde İstanbul-Beyoğlu ve çevresinden bahsetmesi konusundaki düşüncelerine yer verilmiştir. Katılımcıların bu konudaki yorumları genel olarak bakıldığında olumlu olarak değerlendirilmiştir. Ancak katılımcılardan sadece bir kişi konu hakkında bilgisi olmadığını belirtmiştir.

Gerçekleştirilmiş olan bu araştırma kapsamında, toplamda 22-25 yaş arasındaki on yedi katılımcının verdiği yanıtlar çerçevesinde oluşmaktadır. Katılımcıların eğitim durumları lisans, yüksek lisan ve doktora olarak değişmektedir. Buna ek olarak çalışma durumları sırasıyla iki kişi öğrenci, sekiz kişi çalışıyor, altı kişi çalışmıyor ve son olarak bir kişi freelance şeklinde çalıştığını belirtmiştir. Ayrıca katılımcıların sürekli ikamet adresleri incelendiğinde bir kişi Lüleburgaz, bir kişi Ordu, bir kişi Giresun ve çoğunluklu sayı ile on dört kişi İstanbul olarak belirtmiştir.

Araştırma kapsamında yönlendirilen, altı mülakat sorusu incelendiğinde, alanyazında belirtilen bilgileri destekleyen yanıtlar elde edilmiş olduğu görülmektedir. Bu kapsamda katılımcıların, ortak düşünceleri İstanbul-Beyoğlu ve çevresinin büyük bir tarihe sahip olduğu ve edebi eserlerde İstanbul-Beyoğlu çevresinden bahsedilmesinin hem tarihi zenginliğini ve kültürel özelliklerini destekler nitelikte olduğunun ve hem de turizm açısından oldukça olumlu sonuçlar içerdiğini belirtmektedirler.

Alanyazında belirtildiği gibi sosyal medya doğru kullanılırsa oldukça iyi düzeyde iyileşme sağlanabileceği ve gerçekleştirilen değişimlerin orijinal yapısını tahrip edici özelliği taşıdığı sonucu, araştırma kapsamında elde edilen yanıtların da bu gerçeği destekler nitelikte olduğu görülmektedir. Bununla birlikte yazarların ve şairlerin eserlerinde İstanbul-Beyoğlu çevresinden bahsetmeleri okuyucularda bölge hakkında merak uyandırmasıyla, seyahat etme isteği uyandırmaktadır. Ayrıca tarihi açıdan araştırmacı ve tarihe ilgisi olan kişiler, yaşanan dönemlerden kalan eserleri ve izlenimleri gelip yerinde incelemek için destinasyon tercihlerini bu yönde geliştirmektedirler. Kısacası insanların geçmişlerini araştırmaları ve atalarının gezip gördükleri yerler hakkında, günümüzde kendilerinin de bilgi sahibi olmaları ve merak etmeleri İstanbul-Beyoğlu çevresine gerçekleştirdikleri seyahatlerin sebeplerini açıklamaktadır.

\section{SONUÇ ve ÖNERILLER}

İnsanlar, seyahat etmek istedikleri yerleri seçerken, onları motive edebilecek birçok etkene ihtiyaç duymaktadırlar. Bu etkenler kişilerin, kişisel özelliklerine, ilgi alanlarına, yaşadıkları toplum ve aile kültürleri gibi etmenlere bağlı kalarak değişiklik göstermektedir. Ancak seyahat planları yapılırken gidilecek bölgenin tarihi ve kültürel özellikleri, konumu ve benzeri detaylar hakkında bilgi edinilmektedir. Turistler tarafından yapılan bu araştırmalar sonucunda, bölge hakkında ya merak duygusu artmakta ya da bir başka destinasyona yönelim oluşabilmektedir. İstanbul ise gerek coğrafi konumu açısından gerekse kültürel ve tarihi zenginliği açısından dünya genelinde oldukça önemli bir yer teşkil etmektedir. Ayrıca konumu gereği Asya ülkelerinden Avrupa ülkelerine veya tam tersi gidiş gelişlerde turistler için aktarma şehri olarak da kullanılmaktadır.

18-25 yaş arasındaki genç bireyler, ülkeler için oldukça önem taşıyan grubu oluşturmaktadır. Değişen düzene çabuk adapte olabilme, sürekli okuyup yazarak kendilerini geliştirme, farklı kültür ve değerlere açık olma gibi nitelikleri taşıyabildikleri için ülkeler adına sürekli yatırım yapılarak her anlamda geliştirilmek istenen yaş grubudur. 18-25 yaş arasındaki gençlerin gerçekleştirdiği seyahatlere, gençlik turizmi denmektedir. Gençler bulundukları yaştan ve günümüzdeki imkânlarından dolayı açık görüşlü ve karşılaştırma yapan, doğru olanı görerek bunu dile getirebilen kesimdir. Bu doğrultuda sosyal medyayı oldukça aktif kullanmaktadırlar. 
Bir konu ve bölge hakkındaki bilgileri internet üzerinden edinebilmektedirler. Buna ek olarak seyahatlerini internet aracılığıyla kendileri organize ederek en hesaplı ve en uzun şekilde organize etmektedirler.

Tüm bu bilgiler göz önünde bulundurularak yapmış olduğumuz çalışmada on yedi 22-25 yaş arasındaki katılımcıların, İstanbul-Beyoğlu ve çevresinin tarihi dokusunu, ilk seyahatleri ile son seyahatleri sırasındaki izlenimlerini karşılaştırmaları, yabancı turistlerin bu bölgeleri ziyaret etme durumları, sosyal medyanın etkisini ve son olarak ebedi eserlere konu olması hakkındaki düşünce ve değerlendirmeleri konu alınmıştır. Buna istinaden elde edilen sonuçlar alanyazında (Dinçer ve Ertuğral, 2000; Belge, 2010; Oğuz, 2011; Aksoy ve Robins, 2011; Yaşar, 2012; Akgül, 2017; Erbey, 2017) belirtilen bilgileri desteklemektedir. Araştırma kapsaminda elde edilen yanıtlar değerlendirildiğinde İstanbul-Beyoğlu çevresinin tarihi dokusu hakkında, kozmopolit bir yapısı olduğundan, çok uluslu bir yapısının var olduğu, diğer semtlere göre Beyoğlu'nun aykırı bir yapısının olduğundan, ancak mimari yapılarına eskisi kadar değer verilmediğinden ve restorasyon adı altında tahrip edildiği sonucuna varılmıştır. Katılımcılar ilk ziyaret ettiklerindeki izlenimleri ile son gittiklerindeki izlenimleri karşılaştırıldığında, genel sonuç olarak eskiye göre günümüzde tahrip edilmelerin meydana geldiğinin ve tarihi dokusunun silinmeye başladığını belirtmektedirler. Bu değişimin sebeplerini değişen yabancı turist profiline de bağlamaktadırlar. Bir diğer soruya verilen cevaplar birbirine destekleyen niteliktedir.

Yabancı turistlerin gelişini tarihi değerlere önem verdiklerine, iki farklı kültür olan Doğu ve Batı kültürünü yansıttığını düşünerek olumlu açıdan değerlendirmektedirler. Fakat katılımcıların bazıları ise bu durumu değişen turist profiline bağlayarak düzensiz ve tahrip edici şeklinde değerlendirmektedir. Ancak elde edilen yanıtlar genel olarak değerlendirildiğinde İstanbulBeyoğlu ve çevresinin tarihi ve kültürel zenginliğinden kaynaklandığını düşünmektedirler. Ayrıca katılımcıların sosyal medya hakkındaki düşünceleri incelendiğinde, sosyal medyanın aktif kullanılmasından kaynaklı turistlerin paylaşılan fotoğraflar ile reklamları yapılarak ilgi uyandırabilmektedir. Ancak katılımcılara göre, geliştirilmeli yani daha faydalı bilgiler ile aktif bir şekilde kullanılması gerekmektedir. Edebi eserler değerlendirildiğinde ise, katılımcılar bu durumu eserlerden bilgiler edinildiği ve her eser kendi yazıldığı dönem hakkında bilgi aktardığ 1 için insanlar okuduğu zaman o bölgeleri gidip görme isteği duymaya başlamaktadır. Böylelikle o bölgenin turist potansiyelini arttırdığı düşünülmektedir ve bunun da olumlu bir durum olarak değerlendirmektedirler. Katılımcıların düşünceleri değerlendirildiğinde ortaya çıan nihai sonuç, İstanbul-Beyoğlu ve çevresine yapılan düzenlemeler ve restorasyonlar orijinal hallerini bozmamalıdır. Sosyal medya kullanımı ise daha aktif ve bilgilendirici şekilde düzenlenmeli ve kullanımı bu şekilde devam ettirilmelidir.

Gerçekleştirilmiş olan çalışmada kısıtlar bulunmaktadır. Bu kısıtlardan en önemlisi covid-19 virüs salgını nedeniyle mülakat soruları katılımcılara internet ortamında ulaştırılmıştır. Araştırma kapsamında 18-24 yaş arasındaki bireyler tercih edildiği için düşünceler tek bir yaş grubunu kapsamaktadır. Eğer genişletilmek istenirse daha fazla kişi ile farklı yaş gruplarındaki kişilerin düşünce ve değerlendirmeleri karşılaştırılabilir. Araştırmanın evreni olarak sadece İstanbul-Beyoğlu yerine daha geniş bir mekânda tercih edilebilir. Bunlara ek olarak İstanbul'un özellikle Beyoğlu ve çevresi gibi kültürel değere ve zenginliğe sahip olan bölgelerin tarihi değerleri korunmalı ve sahip çıkılmalıdır. Restorasyon adı altında kültürel ve tarihi yapıtların özellikleri bozulmamalıdır. Eski dokusu ve kültürü korunmalıdır. Bu doğrultuda sosyal medyada yapılan reklamlar ve tanıtımlar bölge hakkında geçmiş değerlerini yansıtabilen, merak uyandırabilen türde olmalıdır. Son olarak İstanbul-Beyoğlu bölgesinin yazarlar ve şairler tarafından geçmişte ve günümüzde eserlerinde konu almaları dönemler arasındaki farklılıkları ve benzerlikleri daha somut bir şekilde görmemize neden olmaktadır. Bu tür yazılı belgelere sahip çıkılarak, insanlar teşvik edilmelidir. 


\section{KAYNAKÇA}

Acır, E. (2010). Türkiye'de gençlik turizmi potansiyelinin geliştirilmesi ve çözüm önerileri. Ankara: T.C. Kültür ve Turizm Bakanlığı Yatırım ve İşletmeler Genel Müdürlüğü.

Akgül, A. (2017). Osmanlı-Türk Romanında İstanbul Tasvirleri ve Perspektif Kullanımı. A. A. Feridun M. Emecen (Dü.), Uluslararası Osmanlı İstanbul'u Sempozyumu IV içinde (ss:495-520). İstanbul: İstanbul 29 Mayıs Üniversitesi Yayınları.

Aksoy, A. and Robins, K. (2011). Changing urban cultural governance in Istanbul: The Beyoğlu plan. Culture Policy and Management Research Centre, İstanbul, No. 1.

Altuntuğ, N. (2012). Kuşaktan kuşağa tüketim olgusu ve geleceğin tüketici profili. Organizasyon ve Yönetim Bilimleri Dergisi, 4(1), 203-211.

Aratimur, V. ve Akgündüz, Y. (2018). Yabancı turistlerin destinasyon seçimine sığınmacıların etkisi: Türkiye'ye yönelik bir araştırma. Alanya Akademik Bakış Dergisi, 2(2), 157-175.

Atan, M. ve Arslantürk, Y. (2015). Dünya ülkelerin turizm potansiyelinin etkinliği. Gazi İktisat ve İsletme Dergisi, 1(1), 59-76.

Başbayram, R. ve Turan, A. H. (2018, Ekim). Gençler arasında sosyal medya kullanım karakteristikleri. H. K. İlter (Dü.), 5th International Management Information Systems Conference. içinde Ankara: Ankara Yıldırım Beyazıt University.

Belge, M. (2010). İstanbul: Geçmiş ve Gelecek. İ. Pala, B. Ayvazoğlu, İ. Ortaylı, H. Dursun, S. Genim, B. Murat, H. Barutçugil içinde, Şehir ve kültür: İstanbul (ss:297-320). İstanbul: T.C. Kültür ve Turizm Bakanlığı İstanbul Kültür ve Turizm İl Müdürlüğü.

Cavlak, N. ve Cop, R. (2019, Güz). Yerli ve yabancı turist deneyimi: Gelibolu yarımadası Tarihi Milli Parkı Milliyet temelinde bir analiz. Turizm Araştırmaları Dergisi, 30(3), 163 - 173.

Çelebioğlu, B. ve Yergün, U. (2019). Pera Palace hotel construction technology. MEGARON, 14(1), 11-17.

Çetintürk, V. E. ve Küçük, H. (2019). Gençlik politikalarında karşılaştırmalı bir değerlendirme: Türkiye ve Finlandiya örneği. İktisadi ve İdari Bilimler Fakültesi Dergisi, 24(2), 263-284.

Çuhadar, M. ve Kervankıran, İ. (2015, Aralık). Turizmin sürdürülebilirliğine yönelik yabancı turistlerin alg1 ve tutumları: Marmaris örneği. SDÜ Fen Edebiyat Fakültesi Sosyal Bilimler Dergisi, 2(36), 139-166.

Demir, İ. (2007). Gençlerin kimlik yapıları: Farklı yerellikler ekseninde nitel bir araştırma. Doktora Tezi, İstanbul Üniversitesi, Sosyal Bilimler Enstitüsü-Eğitimde Psikolojik Hizmetler, İstanbul.

Dinçer, F. i. ve Ertuğral, S. M. (2000). Kültürel mirasın korunması ve İstanbul ilindeki tarihi yapıların turizm amaçlı kullanımı üzerine bir deneme. Turizm Araştırmalan Dergisi, 11(2), 69 - 78.

Doğan, M., Pekiner, A. B. ve Karaca, E. (2018). Sosyal medyanın turizm ve turist tercihlerine etkisi: Kars-Doğu Ekspresi örneği. Seyahat ve Otel İşletmeciliği Dergisi, 15(3), 669-683.

Erbaş, A. E. (2018). Cultural heritage conservation and culture-led tourism conflict within the historic site in Beyoğlu, Istanbul. WIT Transactions on Ecology and the Environment, 217(13), 647659.

Erbey, D. (2017). Changing cities and changing memories: The case of Taksim Square, Istanbul. International Journal of Culture and History, 3(4),203-212. 
Kahraman, N. (2014). İstanbul'un turizm arz-talep yapısı ve gelişimi. İstanbul Ticaret Üniversitesi Sosyal Bilimleri Dergisi, 13(25), 163-190.

Karabulut, M. (2010). Tanzimat dönemi Türk romanlarında İstanbul ve Paris'e bakış. Erdem, 1(56), 103-113.

Karataş, İ., Altun, Ö. ve Cizrelioğulları, M. N. (2020). Gençlik turizmi'ne üniversiteli gençlerin bakış açısı: Doğu Akdeniz ile Kocaeli Üniversitesi karşılaştırılması. Türk Turizm Araştırmaları Dergisi, 4(3), 314-332.

Kazandzhieva, V. and Popova, K. (2017). Assessment of the impact of meso- environmental factors on the youth tourism in Bulgaria. Izvestia Journal of the Union of Scientists - Varna. Economic Sciences Series, 7(1), 158-171.

Oğuz, B. (2011). Gustave Flaubert'ın İstanbul destinasyonu. Pamukkale Üniversitesi Sosyal Bilimler Enstitüsü Dergisi, 3(8), 47-56.

Soylu, A., Özdipçiner, N. S. ve Ceylan, S. (2018). Yerli ve yabancı turistlerin destinasyon imajına ilişkin algı farklılıkları: Pamukkale örneği. Hitit Üniversitesi Sosyal Bilimler Enstitüsü Dergisi, 11(3), 2481-2493.

Topuz, M. (2018). Tatil yeri seçiminde reklamlarin rolü: İstanbul ilini ziyaret eden yabancı turistler üzerine bir araştırma. İşletme Bölümü. Kırklareli: Kırklareli Üniversitesi.

Ural, H. (2017). Beyoğlu'nun gece yaşamı ve neoliberal iktidar teknolojileri. Kent Araştırmaları Dergisi, 8(22), 26-57.

https://tr.wikipedia.org/wiki/Beyo\%C4\%9Flu. [Erişim Tarihi: 25.08.2020].

Yaban, P., M. A., Sunar, D., Kılıç, A. C., Özalp, D. ve Kazak, H. (2019). İstanbul'da büyük ölçekli kentsel projeler ve planlama süreçleri. (H. F. Meşhur, K. Ertuğay, F. Eren, ve C. Korkmaz, Dü) Ankara: Atalay Matbaacilik.

Yaşar, H. (2012). Ahmet Ümit'in Beyoğlu rapsodisi'nde mekân olarak "Beyoğlu". Ç.Ü. Sosyal Bilimler Enstitüsü Dergisi, 21(2), 37-58.

Yıldırım, A. (2018). Kültür varlıklarının korunması bağlamında toplumsal bellek: Meydanlar (Taksim meydanı örneği). Kadir Has Üniversitesi , Mimarlık Anabilim Dalı. Fen Bilimleri Enstitüsü .

Zengin, B., Kıngır, S. ve Tezcan, N. Ş. (2018). Gençlerin turizm algısı ve turizme verilen destek; Sakarya üniversitesi öğrencileri üzerine bir araştırma. Bartın Üniversitesi İktisadi ve İdari Bilimler Fakültesi Dergisi, 9(18), 147-168. 